\title{
腰部脊柱管狭窄症に対する椎弓切除術の術後成績
}

\author{
長崎三菱病院整形外科 \\ 坂 本 和 隆・瀬 良敬 祐 \\ 中 村昌一・山本尚幸
}

\section{A Study of Surgical Treatment of Lumbar Canal Stenosis}

\author{
Kazutaka Sakamoto, Keisuke Sera, Masakazu Nakamura, \\ and Takayuki Yamamoto \\ Department of Orthopedic Surgery, Nagasaki Mitsubishi Hospital
}

\begin{abstract}
We performed laminectomy on patients with lumbar canal stenosis for the decompression of the lumbar spine. Instability of the lumbar spine is a serions postoperative complication. In this paper, 88 patients with lumbar canal stenosis without degenerative spondylolisthesis were reviewed in clinical and radiographical investigation. 28 patients were famale and 60 were male. The mean age was 64.1 years (range, 33-84). The average follow-up time was 30.2 months (range, 11-73). 23 patients were treated with total laminectomy and 65 were treated with partial laminectomy. The postoperative results were evaluated with the JOA score. The mean preoperative JOA score was 14.4 points and the mean postoperative JOA score was 23.1 points. The recovery rate was $59.8 \%$. Postoperative instability of the lumbar spine was found in 9 patients (10.2\%), but postoperative instability did not always correlate with the clinical symptoms. Thus, laminectomy is a safe and useful procedure for lumbar canal stenosis without degenerative spondylolisthesis.
\end{abstract}

Key words : lumbar canal stenosis (腰部脊柱管狭窄症), instability（不安定性), laminectomy（椎 弓切除術)

はじめに

腰部脊柱管狭窄症に対して除圧術を施行する際, 脊 椎固定術の適応については諸家により多くの報告がな されている．除圧術のみで良いとする報告 ${ }^{6 / 8)}$ がある 一方, 固定術を併用しない場合, 術後不安定性による 臨床成績の低下屯報告 ${ }^{1 / 3) 7)}$ されている，我々は明ら かな不安定性を有する例や変性すべりを伴う例に対し ては基本的に固定術を併用し，その他の例には除圧術 のみで対応している. 今回, 変性すべりを伴わない腰 部脊柱管狭窄症に対し, 椎弓切除術を行った症例の術 後成績及び, 術後不安定性の有無とその臨床成績との 関連を術式別に検討したので報告する.
対

象

1989 より 98 年までの間に当科にて腰部脊柱管狭窄 症の診断で手術を行った症例のうち, 変性すべりを伴 わない症例に対して Total laminectomy（以下, Total.) 又は Partial laminectomy（以下, Partial.) の みを行い，固定術を併用しなかったものは 108 例であ る.このうち追跡調查可能であった 88 例（男性 60 例, 女性 28 例）について検討した。手術時年齢は 33-84 歳, 平均 64.1 歳. 経過観察期間は 11-73 ケ月, 平均 30.2 ケ月. 術式は Total. 23 例, Partial. 65 例であっ た. 
方法

術前・術後の日整会腰痛疾患治療判定基準（以下, JOA score) とその改善率（平林法）を計測し, 術式 別に改善率を比較した. 改善率を優・良・可・不可と $25 \%$ 毎に区分し, 術後成績不良例について検討した.

術後不安定性については, 術前・術後の腰椎 X線前 後屈側画像で前後届椎間可動角, 前後屈すべり距離を それぞれ計測し, 術前・術後の変化について術式別に 評価した. 前後屈椎間可動角 $10^{\circ}$ 以上または, 前後屈 すべり距離 $3 \mathrm{~mm}$ 以上のものを不安定性ありとし, それらの術後成績を検討し, 不安定性のない症例との 比較を行った。

\section{結果}

JOA score は術前平均 14.4 点から 23.1 点へと改善 し, 平均改善率は $59.8 \%$ であった。術式別改善率は, Partial. 61.9\%, Total. 54.1\%であったが，両者に有 意差を認めなかった. 改善率の区分では, 優 26 例, 良 30 例, 可 26 例, 不可 6 例であった（表 1 ）. 不可 の 6 例の平均年齢は 66.8 歳, 術式は Partial. 3 例, Total. 3 例であり, 脳梗塞 2 例, 精神的疾患 1 例, 変 形性関節症及び糖尿病 1 例の合併症がみられた。 その 他の症例 82 例の平均年齢は 63.9 歳であり, 不可 6 例 の 66.8 歳と有意差を認めなかった。 また，合併症は 脳梗塞 4 例, 糖尿病 3 例, 慢性関節リウマチ 2 例, 変 形性関節症 2 例, 動脈閉塞症 2 例, 䩄椎症性脊㖪症 1 例, 白血病 1 例であり, 合併症を有する例は平均改善 率 $48.1 \%$ と低い傾向を認めた.

前後屈椎間可動角は術前平均 $7.14^{\circ}$ から術後 $7.64^{\circ}$ 人 $0.50^{\circ}$ 増加, 前後屈すべり距離は術前平均 $0.57 \mathrm{~mm}$ か ら術後 $1.01 \mathrm{~mm}$ へと $0.44 \mathrm{~mm}$ 増加した. 術式別の前後 届椎間可動角は Partial. 術前平均 $7.78^{\circ}$ から術後 $8.30^{\circ}$ へ $0.52^{\circ}$ 増加, Total. 術前平均 $5.28^{\circ}$ から術後 $5.76^{\circ}$ 人 $0.48^{\circ}$ 増加し, 術式別に有意差を認めなかった，前後 屈すべり距離は Partial. 術前平均 $0.62 \mathrm{~mm}$ から術後 $1.05 \mathrm{~mm}$ へ $0.43 \mathrm{~mm}$ 増加, Total. 術前平均 $0.43 \mathrm{~mm}$

表 1 JOA score 改善率

\begin{tabular}{l|c|rrrc}
\hline \hline & 平均改善率 & 優 & 良 & 可 & 不可 \\
\hline Partial. & $61.9 \%$ & 21 & 21 & 20 & 3 \\
Total. & $54.1 \%$ & 5 & 9 & 6 & 3 \\
\hline 全 体 & $59.8 \%$ & 26 & 30 & 26 & 6 \\
\hline
\end{tabular}

加術後 $0.91 \mathrm{~mm}$ へ $0.48 \mathrm{~mm}$ 増加し, 術式別に有意 差を認めなかった（表 2 ).

前後屈椎間可動角 $10^{\circ}$ 以上または, 前後屈すべり距 離 $3 \mathrm{~mm}$ 以上のものは 88 例中 9 例に認められた。 そ の平均年齢は 63.4 歳, 術式は Total. 3 例, Partial. 6 例, 平均改善率は $51.4 \%$ であり, 優 2 例, 良 3 例, 可 3 例，不可 1 例であった，不安定性のない 79 例の 平均年齢は 64.2 歳, 術式は Total. 20 例, Partial. 59 例，平均改善率は $60.8 \%$ であった，不安定性を認めた 9 例と不安定性のない 79 例の平均年齢, 改善率に有 意差を認めなかった。

症例を供覧する.

【症例 1 】 70 歳, 女性 主訴：右下肢痛, 間欠性跛 行

ミェログラムで L $3 / 4$ に狭窄， L4/5 にブロックを 認める (図 1 ). L3/4, 4/5 に Partial laminectomy を行った．合併症に慢性関節リウマチを認めた．術後 1 年 3 力月のX線で L $4 / 5$ にすべりを認め, 前後屈す ベり距離 $3 \mathrm{~mm}$, 前後屈椎間可動角 $12^{\circ}$ であった（図 2). JOA score は 13 点から 18 点に改善し, 改善率

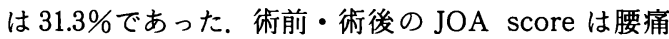
$2 \rightarrow 3$ 点, 下肢痛・しびれ $0 \rightarrow 0$ 点, 跛行 $1 \rightarrow 2$ 点, ADL $6 \rightarrow 7$ 点, 神経学的所見 $4 \rightarrow 6$ 点と改善した. 下肢痛・しびれは改善せず, ADL が 1 点の改善にと どまっており，慢性関節 リウマチが関与していると 考えられた。

【症例 2】77 歳, 男性 主訴：両下肢しびれ，間欠 性跛行

ミエログラムでL4/5 にブロックを認める（図 3 ）. L4, L5にTotal laminectomy を行った. 術後 1 年 のX線（図 4 ）では L4/5 に前後屈すべり距離 $3 \mathrm{~mm}$, 前後屈椎間可動角 $10^{\circ}$ と不安定性を認めた。JOA score は 18 点から 25 点に改善し，改善率は $63.6 \%$ で あった. 術前・術後の JOA score は腰痛 $2 \rightarrow 3$ 点, 下肢痛・しびれ $1 \rightarrow 3$ 点, 跛行 $1 \rightarrow 3$ 点, ADL10 $\rightarrow$ 10 点, 神経学的所見 $4 \rightarrow 6$ 点と改善し, 腰椎不安定 性による影響は特に認められなかった。

表 2 術後不安定性

\begin{tabular}{l|c|c}
\hline & 前後屈椎間可動角 & 前後屈すべり距離 \\
\hline Partial. & $+0.52^{\circ}$ & $+0.43 \mathrm{~mm}$ \\
Total. & $+0.48^{\circ}$ & $+0.48 \mathrm{~mm}$ \\
\hline 全 体 & $+0.50^{\circ}$ & $+0.44 \mathrm{~mm}$ \\
\hline
\end{tabular}




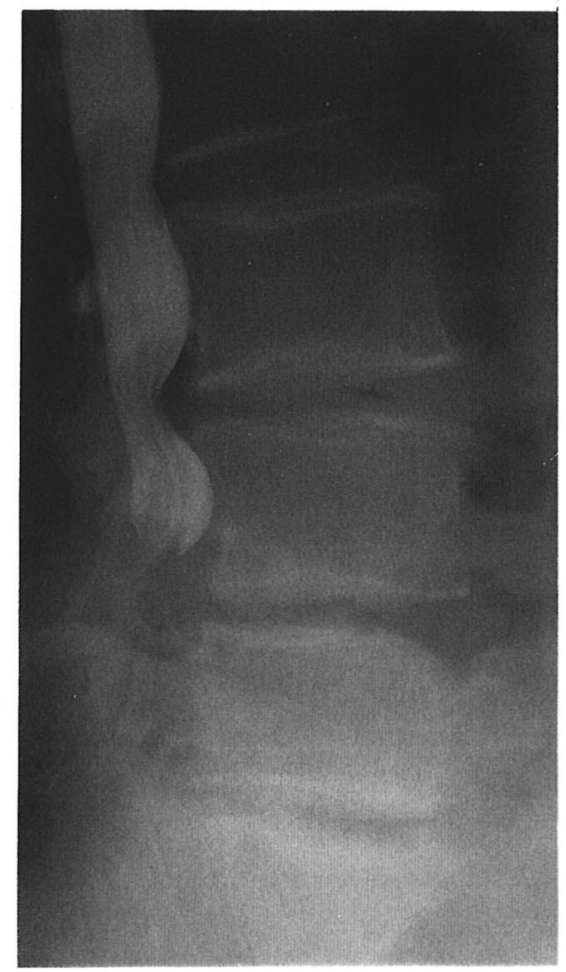

図 1 ミェログラム

L3/4 に狭窄，L4/5 にブロックを認める.

考察

腰部脊柱管狭窄症に対する除圧術の必要性は議論の ない所であるが, 除圧の範囲および, 固定を併用する か否かが常に議論されている。除圧術に関しては，障 害部位を明らかにして十分な除圧を考虑するとともに， 椎弓及び椎間関節への侵襲を最小限に留めることが重 要であるが, 術後不安定性による臨床成績への影響に ついては明らかな結論は出ていない, 文献的には除圧 術のみで良(6)8) とする報告がある一方, 固定術を併 用しない場合, 術後不安定性による臨床成績の低下む 報告(1)37) されている. 我々は明らかな不安定性を有 する例や変性すべりを伴う例に対しては基本的に固定 術を併用し, その他の例には除圧術のみで対応してい る.

我々の症例の全体の平均改善率は $59.8 \%$ であり, 諸 家の報告 ${ }^{2) 4)}$ と比して大差は認められなかった。 また， 術式別改善率（Total. 54.1\%, Partial. 61.9\%) にも 有意差は認められず, Partial laminectomy では除

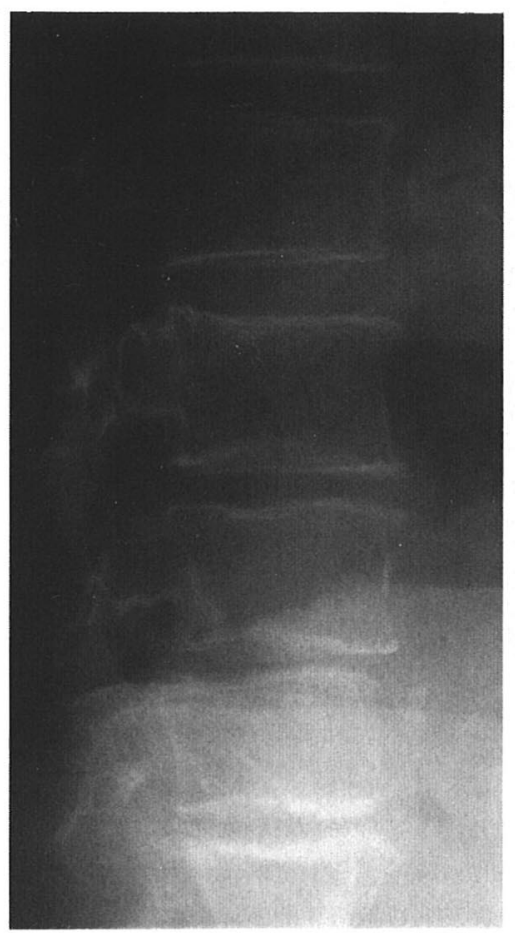

図 2 術後 1 年 3 力月

L4/5 にすべりを認める.

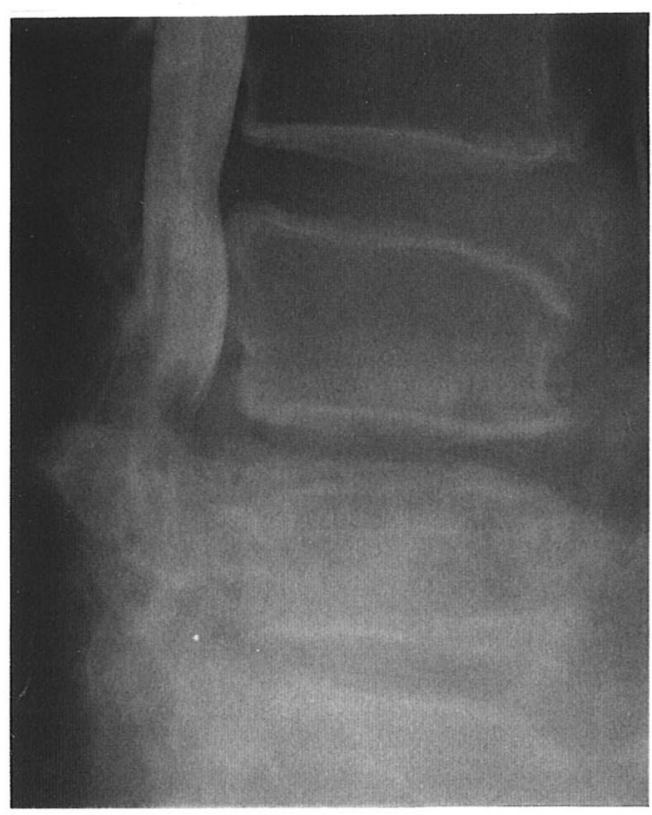

図 3 ミエログラム

L4/5 にブロックを認める. 


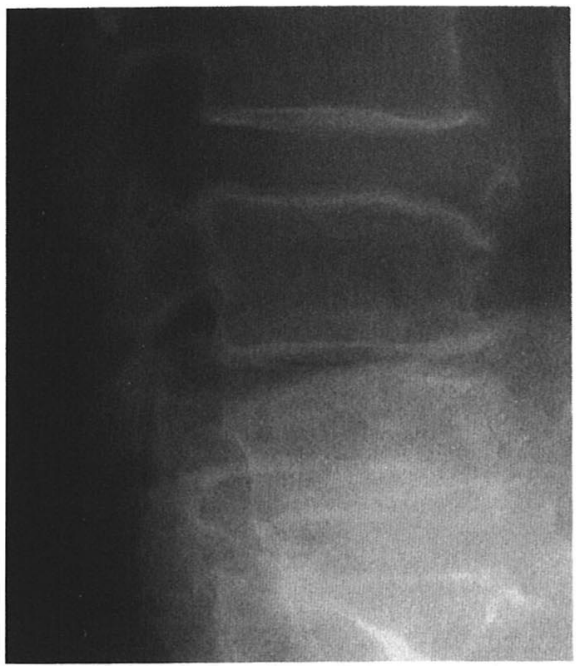

図 4 術後 1 年

L4/5 に不安定生を認める.

圧が十分でないと考えられる症例には Total laminectomy を考慮してもよいと考えられる.

改善率 $25 \%$ 以下の 6 例の平均年齢は 66.8 歳とその 他の症例と比して差を認めない. 6 例中 4 例に合併症 がみられ, 残り 2 例は, 84 歳と非常に高齢で麻痺が 残存した一例と, 術後も下肢痛が改善せず, 再手術で 神経根に痹着した瘕痕組織が認められたいわ沈る postoperative type の一例であった，改善率 25\%以 上の症例についても, 合併症を有する 15 例の平均改 善率 48.1\%は全体の平均改善率 $59.8 \%$ と比して低值で あり, 術後成績に合併症は大きく影響を及ぼすと考え られた。

腰椎不安定性の評価として, 前後屈椎間可動角・前 後屈すべり距離を測定したが, 術後不安定性の生じた のは 88 例中 9 例 $\left(10.2 \%\right.$ ）であり，大澤ら ${ }^{6)}$ ，小原 らら)の報告と比して大差を認めなかった。 また，不安 定性のない 79 例 (89.8\%) と比して平均年齢, 術式 や改善率に有意差は見られなかった。このことより変 性すべりを伴わない腰部脊柱管狭窄症に対し, 椎弓切 除術は有効な方法であり，臨床成績に影響するような 不安定性は生じないと思われた.

我々の施設において, 変性すべりを伴う腰部脊柱管
狭窄症について調査した穂積らの発表（第 97 回西日 本整災）によると，椎弓切除術に後側方固定・instru ment を併用した例の JOA score 平均改善率は 72.2 $\%$, 椎弓切除術単独例の平均改善率は $43.7 \%$ 之有意差 を認め, 後側方固定・instrument を併用した例は術 後不安定性む少ないという結果であった。このことよ り, instrument は広範な除圧之腰椎の固定に有用で あると考えられるが，変性すべりを伴わない症例では 不安定性の発生を危惧し，予防的に固定術や instrument を併用することは過度の侵襲を与えることであ り，症例を慎重に検討すべきと思われる.

結語

1. 変性すべりを伴わない腰部脊柱管狭窄症に対し て, 椎弓切除術を行った症例の術後成績を検討した.

2. JOA score は平均 14.4 点加ら 23.1 点へと改善 し, 平均改善率は $59.8 \%$ と比較的安定した結果がえら れた.

3，術前に変性すべりを伴わない腰部脊柱管狭窄症 に椎弓切除術は有効な方法であると考えられた。

\section{参 考 文 献}

1）伊藤拓緯・他：腰部脊柱管狭窄症に対する手術療法の 检討. 東北整災紀要, 35 : (1) 33-36, 1991.

2）久木田裕史・他 : 腰部脊柱管狭窄症に対する拡大開品 術の術後成績. 整形・災害外科, 42：(10)1163-1167, 1999 .

3) Lee CK : Lumner spinal instability (olisthesis) after extensive posterior spinal decompression. Spine, 8 429-433, 1983.

4) 松本宏一・他：腰部脊柱管狭窄症に対する椎弓切除術 と後側方固定術の併用法について。整形・災害外科, 36 (4) $1242-1247,1988$.

5）小原 進・他：腰部脊柱管狭窄症に対する椎弓切除術 の術後成績. Spinal Surgery, 9:87-94，1995.

6）大澤良充，竹内則博：高齢者の腰部脊柱管狭窄症に対 する椎弓切除術の長期成績. 中部整災誌, 38(3)599-600, 1995.

7) Silvers HR, Lewis PJ, Asch HL : Decompressive lumber laminectomy for spinal stenisis. J Neurosurg, 78 : 695-701, 1988.

8）襄辻雅章, 栗原 章, 謝 典穎: 腰部脊柱管㹨窄症に 対する広範囲椎弓切除術の成績. 臨整外, 27 ：(4)429436, 1992 